\title{
The conflict between Damasus and Ursinus Damasus's contested legitimacy as bishop of Rome
}

\author{
Kristiaan VENKEN \& Anthony DUPONT
}

\section{OVERVIEW OF THE CONFLICT}

On 24 September 366, Liberius, bishop of Rome, died. Two deacons of Liberius, Damasus and Ursinus, competed to succeed him. Their struggle has been described and analyzed by many scholars on the basis of contemporaneous sources ${ }^{1}$. These sources relate the conflict in more or less detail and provide their own, sometimes quite partisan, interpretation. In the briefest of terms, the following events have been identified as taking place after Liberius's death and before Damasus finally managed to impose himself as Liberius's successor: the election of both candidates, their ordination, and one or more violent clashes between their supporters ${ }^{2}$.

In this essay, we analyze the background and details of these events, the rivalries that were at play, and the sources that report them. We also make a determination as to which of the candidates was entitled to be the new bishop of Rome, according to the criteria then acknowledged for a valid episcopal succession. Both candidates passed through the necessary steps, but because Damasus managed to secure popular approval in the form of a public acclamation and Ursinus did not, Damasus was finally able to succeed Liberius as bishop of Rome, and should be viewed as his valid successor.

The scholarship on the said Roman conflict contains many debated claims, for which our article offers an extensive state of the art and evaluation. For instance, some scholars draw their conclusions chiefly based upon their reading of one of the most extensive sources, the Quae gesta sunt inter Liberium et Felicem (Gesta). The latter, however, is composed by supporters of Damasus's opponent Ursinus, and thus clearly has an anti-Damasus motivation. Using this document as the main source for the conflict and its outcome, and with the other contemporaneous sources providing only limited information, scholars have been too quick to copy the view of the Gesta, which has in turn colored their conclusions, most often not to the credit of Ursinus. This article, furthermore, advances scholarship by comparing the parallel election of Damasus and Ursinus with similar double elections to the See of Peter in Late Antiquity. This comparison is aimed at establishing criteria for a valid succession. In this way, we will argue that certain details, such as the exact chronology of the events, despite being considered important by ancient sources and later scholarship, mattered less

\footnotetext{
${ }^{1}$ An overview of scholarship on the topic is provided by M. Löx, Monumenta sanctorum. Rom und Mailand als Zentren des früben Christentums. Märtyrkult und Kirchenbau unter den Bischöfen Damasus und Ambrosius, Wiesbaden, Reichert Verlag, 2013, p.27, n.60. A chronological table of the events may also be found in A. CoŞKUN, Der Praefect Maximinus, der Jude Isaak und der Strafprozess gegen Bischof Damasus von Rom, in Jabrbuch für Antike und Christentum 46 (2003) 17-44, p.43-44; and in R. LIZZI TESTA, Senatori, popolo, papi. Il governo di Roma al tempo dei Valentiniani (Munera 21), Bari, Edipuglia, 2004, p.169.

${ }^{2}$ U. ReUTTER, Damasus, Bischof von Rom (366-384). Leben und Werk, Tübingen, Mohr Siebeck, 2009, p.41.
} 
than the formal correctness of the succession procedure. Our study shows that public approval of a candidate, not mentioned in the primary sources and only lately taken into account, is a fundamental factor in the succession process. We will also show, finally, that the background of both candidates does matter. This is not, as the Gesta seems to suggest, their prior history of orthodoxy, but their function as a deacon, as well as the support they enjoyed, on a very local and political level. In this context the influence of the Roman aristocracy also played a role, and our article builds on and deepens the research of recent studies on the latter.

\section{SOURCES}

Detailed, unbiased, and contemporary sources about the succession conflict do not exist. Available sources favor one of the candidates, omit details, or were written at some distance in time from the events.

The disputed succession is referred to in Damasus's biography in the Liber Pontificalis. Ammianus also describes it in a detailed way. Jerome, Rufinus, Socrates Scholasticus, and Sozomen (the latter two dependent on Rufinus) offer reports that are similar to each other and portray Damasus positively.

The most detailed description of the conflict is found in a polemical text composed by Damasus's opponents and preserved among the first documents of the Collectio Avellana. Additional sources include Damasus's later correspondence with other bishops, his correspondence with Jerome, and his epigrams ${ }^{3}$. References to Ursinus or to his conflict with Damasus are also found in several other sources: for example in documents from the Collectio Avellana that preserve some of the communication between emperors and the Roman city authorities; in the imperial correspondence with Ambrose; and finally in a synodal letter communicating the outcome of a Roman council presided over by Damasus ${ }^{4}$.

The Collectio Avellana is "a mid-sixth-century collection of nearly 250 documents relating to the bishopric of Rome in the fourth, fifth, and sixth centuries"5. References to Damasus or to his conflict with Ursinus can be found in a number of texts from the beginning of this collection, specifically in documents 1,2, and 5-13. The first text, entitled Quae gesta sunt

\footnotetext{
3 See M. Löx, Monumenta sanctorum, p.25-26.

${ }^{4}$ Letters 4-13 in the Collectio Avellana, cf. M. Löx, Monumenta sanctorum, p.26, n.51, quoted above. For further references to these letters of Ambrose, see M. RAIMONDI, Elezione iudicio Dei $e$ turpe convicium. Damaso e Ursino tra storia ecclesiastica e amministrazione romana, in Aevum 83 (2009) 169-208, p.197: Ep. X; RAIMONDI, Elezione iudicio Dei, p.203: Ep. extra coll. V; and cf. F. A. POGLIO, Gruppi di potere nella Roma tardoantica (350-395 d.C.), Torino, Celid, 2007, p.156: Ep. extra coll. VII. This last document contains the synodal letter of a Roman council held under Damasus. See LIZZI TESTA, Senatori, popolo, papi, p.171, n.269. ${ }^{5} \mathrm{~K}$. BLAIR-DixOn, Memory and authority in sixth-century Rome. The Liber Pontificalis and the Collectio Avellana, in K. CoOper \& J. Hillner (ed.), Religion, Dynasty and Patronage in Early Christian Rome, 300-900, Cambridge, Cambridge University Press, 2007, 59-77, p.59. For this dating, Blair-Dixon refers to O. GÜNTHER, Avellana Studien (Sitzungsberichte der Philosophisch-Historischen Classe, 134), Wien, Kaiserliche Akademie der Wissenschaften, 1896, Abh. 5, p.2, n.6.
} 
inter Liberium et Felicem episcopos (Coll. Av. 1), is a pamphlet that describes scenes from the conflict between Damasus and Ursinus; the scenes took place not only immediately after Liberius's death in 366, but also during Liberius's pontificate. The pamphlet was written immediately after the events of 366 - 368 by an author hostile to Damasus. This author's intention in publishing his account of the first conflicts during the time of Liberius was to blacken Damasus's name and thus to prejudice the Italian bishops against him. It has been supposed that this pamphlet was later affixed as a preface (Praefatio) to a petition (Libellus Precum) submitted to the emperor Theodosius by the followers of Lucifer of Cagliari in 383 or 3846; hence the pamphlet is also called the Praefatio. More recently this link between the Gesta and the Libellus Precum has been challenged. According to the revisionist view, the Gesta do not stem from the same archives as the other documents of the Collectio Avellana; instead the Gesta were only added later to the Collectio Avellana by its sixth-century compiler, who also provided the title for both documents and the text linking them. The Gesta and the Libellus Precum would then be originally independent documents. The brief connection that existed in 366 between the authors of both documents, namely, between the supporters of Ursinus who produced the Gesta and those of Lucifer of Cagliari who authored the Libellus, did not exist any more in 383-384 when the Libellus was published ${ }^{7}$. An argument in favor of this thesis is that in Coll. Av. 1,6 the church at which the conflict took place is called the basilica Liberii, which is the name the church bore in the sixth century, rather than the basilica Sicinini, which is the name the church bore in the fourth century ${ }^{8}$. Another indication that both documents originated independently is that in the Libellus Precum Ursinus is not mentioned at all ${ }^{9}$. Additionally the negative judgment concerning the current city prefect Viventius (Coll. Av. 1,6) would seem to be inappropriate for the preface of an

\footnotetext{
${ }^{6}$ Ch. PIETri, Damase évêque de Rome, in Saecularia Damasiana, Rome, Pontificio Istituto di Archeologia Cristiana, 1986, 29-58, p.33. See also G. De SPIRITO, Ursino e Damaso - una nota, in A. KessLER, T. RICKLIN \& G. WURST (ed.), Peregrina curiositas. Eine Reise durch den «orbis antiquus». Zu Ehren von Dirk Van Damme, Freiburg, Universitätsverlag; Gottingen, Vandenhoeck \& Ruprecht, 1994, 263-274, p.263, who states that, although with some doubt, the Gesta is generally assumed to have originated from the same "UrsinianLuciferan environment" which created the Libellus Precum, for which it may have served as its historicaljuridical preface. The Libellus Precum was included in the Collectio Avellana as Coll. Av.2. O. Günther dates the Libellus Precum to 383 or 384: Otto GUENTHER (ed.), Epistolae imperatorum pontificum aliorum inde ab a. CCCLXVII usque DLIII datae. Avellana quae dicitur collectio (CSEL, 35), Prague, Tempsky; Vienna, Tempsky; Leipzig, Freitag, 1895, p.5.

${ }^{7}$ See R. LIZZI TESTA, Senatori, popolo, papi, p.131-132, and p.154.

${ }^{8}$ See Blair-Dixon, Memory and authority, p.71. See also D. Trout, Damasus of Rome. The Epigraphic Poetry. Introduction, Texts, Translations, and Commentary (Oxford Early Christian texts), Oxford, Oxford University Press, 2015, p.5, n.20, which refers to O. BRANDT, The Early Christian Basilica of San Lorenzo in Lucina, in O. BRANDT (ed.), San Lorenzo in Lucina. The Transformations of a Roman Quarter (Skrifter utgivna av Svenska Instituter Rom, $4^{\circ}$, 61), Swedish Institute in Rome, Stockholm, 2012, 123-154, p.148-151. Trout considers Blair-Dixon's dating of the Gesta to the fifth-sixth century obviated by O. Brandt's archaeological findings regarding the Church of San Lorenzo in Lucina.

9 This same argument is discussed by M. Green in his attempt to ascertain the relationship between the followers of Ursinus and those of Lucifer of Cagliari. See M. GREEN, The Supporters of the Antipope Ursinus, in The Journal of Theological Studies 22 (1971) 531-538. Even if the Gesta are not the Praefatio of the Libellus Precum, E. Di Santo detects in both documents the same anti-Damasus feelings and the same ecclesiological concepts. E. Di SANTO, L'apologetica dell'Ambrosiaster. Cristiani, pagani e giudei nella Roma tardoantica (Studia Ephemeridis Augustinianum, 112), Roma, Institutum Patristicum Augustinianum, 2008.
} 
official document addressed to the emperor and requesting clemency for the followers of Lucifer of Cagliari; consequently the negative remark about Viventius would be proof that the pamphlet did not have an official character ${ }^{10}$. Separating the Gesta from the Libellus Precum, which implies that the Gesta were not (part of) an official document directed to the emperor, removes one of the arguments in favor of the document's reliability. It has been argued that the Gesta must have had a certain historical value, because the emperors reacted positively to it ${ }^{11}$. This positive reaction (Coll. $A v .2 \mathrm{a}$ ), however, is actually in response to the Luciferians' requests in the Libellus Precum (Coll. Av. 2) and not in response to the content of the Gesta inter Liberium et Felicem.

The Gesta are indeed the longest and most detailed document describing the conflict over the succession of Liberius. They offer detailed chronological and topographical information, apparently by someone who knew the situation very well ${ }^{12}$. The trustworthiness of the Gesta is sometimes challenged and sometimes accepted ${ }^{13}$. In favor of their reliability is that the Gesta were written very shortly after the facts and related events that had happened quite recently; hence these events were still in the public domain and widely known ${ }^{14}$. An argument against the Gesta, apart from their internal contradictions, is that the document was produced by a very partisan author ${ }^{15}$.

Another record of the events can be found in Jerome's chronicle for the year $366^{16}$. Jerome had been in Rome in 366 as a student, which makes him a possible eyewitness to the conflict, but his account of the events is short, imprecise, and suppresses details; in fact, in his account Jerome is very "far from sticking to the facts" 17 . When he wrote his report, the conflict with Ursinus was still fresh; perhaps "Jerome had seen no need to open these wounds"18. As his secretary and close collaborator of Damasus between 382 and 384, Jerome's report too is one-sided ${ }^{19}$.

\footnotetext{
${ }^{10}$ So LIZZI TESTA, Senatori, popolo, papi, p.151.

${ }^{11}$ E.g., by G. De SPIRITO, Ursino e Damaso, p.264: "Se le due lettere furono accolte, non potevano avere presentato alle massime autorità una situazione totalmente mistificata dei fatti che in esse si esponevano. La Cancelleria imperiale doveva essere ben informata al riguardo. [...] Alla luce di queste considerazioni si puo concludere che entrambi $i$ testi paiono essere fide digni e che rappresentano uno di quei rari casi in cui si può ascoltare la voce di quanti uscirono perdenti da una lotta sviluppatasi in seno alla Chiesa".

12 According to Massimiliano GHILARDI, Tempore quo gladius secuit pia viscera matris. Damaso, i primi martiri cristiani e la città di Roma, in Gianluca PILARA \& Massimiliano GHILARDI, La città di Roma nel pontificato di Damaso (366-384). Vicende storiche e aspetti archeologici (A11, 659), Roma, Aracne, 2010, 97-186, p.174, and in particular p.174, n.193.

${ }_{13}$ Poglio, Gruppi di potere, p.63, n.151, gives an overview: G. De Spirito, L. Cracco Ruggini and C. Carletti, consider the Gesta to be a trustworthy witness; R. Lizzi Testa however does not.

${ }^{14}$ Poglio, Gruppi di potere, p.63.

15 These internal contradictions, one-sidedness and lack of objectivity were noted by Massimiliano GHILARDI, Tempore quo gladius, p.174, n.192.

16 Jerome, Chron. ad a. 366.

${ }^{17}$ L. CRACCo Ruggini, Rome in Late Antiquity: Clientship, Urban Topography, and Prosopography, in Classical Pbilology 98 (2003) 366-382, p.375, n.49. So also A. LiPPOLD, Ursinus und Damasus, in Historia. Zeitschrift für Alte Geschichte 14 (1965) 105-128, p.109.

18 Trout, Damasus of Rome, p.2.

${ }^{19}$ LIPPOLD, Ursinus und Damasus, p.109.
} 
Rufinus of Aquileia was also in Rome when Damasus became bishop, and he stayed there during the following years. He too must have been a witness to the dramatic events. His account of them is very concise and conceals much ${ }^{20}$. At some chronological distance from the events of the confrontation, and with the conflict settled in favor of Damasus, Rufinus presents what happened but with a negative view of Ursinus ${ }^{21}$.

Socrates of Constantinople or Socrates Scholasticus (ca. 380 - post 439) composed his

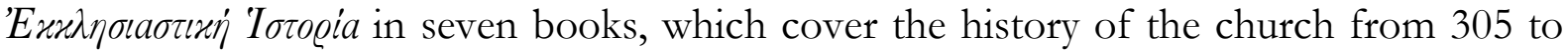
439. In book 4, chapter 29, he discusses the events of the succession of Liberius. It is assumed that Socrates relied primarily on Rufinus in this passage, but certain elements also point to an independent source 22 . Socrates' text, for example, contains a number of new elements, particularly the statements that Ursinus was consecrated by some insignificant bishops - Rufinus writes that it was an inexperienced rural bishop, whom he does not mention by name - and that the consecration took place not in a church, but in a place nearby.

Finally Sozomen, a Christian historian from the first half of the fifth century, wrote a history

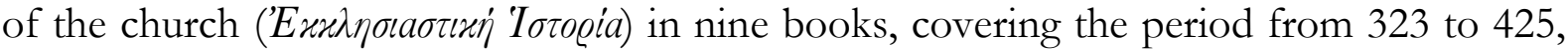
from the emperor Constantine till the accession of the emperor Valentinian III. The difficulties surrounding the succession of Liberius appear in chapter 23 of book 6 . In this passage, Sozomen briefly describes the discord that arose when Ursinus, consecrated bishop shortly after Damasus, tried to succeed Liberius. The text is very similar to, if shorter than, that of Socrates ${ }^{23}$.

Provisionally, we can conclude that Jerome, Rufinus, Socrates, and Sozomen all aim at a Damasus-friendly presentation of the events by blaming the Ursinians for the confrontation ${ }^{24}$.

\footnotetext{
${ }^{20}$ RUFINUS, Hist. Eccl., 11, 10. For the conciseness of Rufinus's account, see LIPPOLD, Ursinus und Damasus, p.109, n.22.

${ }^{21}$ Rufinus wrote his text some thirty years after the events, see L. DATTRINO, Papa Damaso (366-384) nella Storia ecclesiastica di Rufino, in Saecularia Damasiana, Rome, Pontificio Istituto di Archeologia Cristiana, 1986, 149-160, p.151. When he wrote his text around 403 Ursinus had become discredited, and this development according to Lippold (Ursinus und Damasus, p.109) explains Rufinus's distortion of the facts. Lippold's judgment is, as we will argue, too severe where he insists that Rufinus's chronology of the election and ordination of both opponents and the information about the place of Ursinus's ordination is a forgery.

22 For the dependency of Socrates on Rufinus, see e.g., LÖX, Monumenta sanctorum, p.25; and Pierre PÉrichon \& Pierre MARAVAl (ed.), Socrate de Constantinople. Histoire Ecclésiastique. Livres IV-VI (Sources Chrétiennes, 505), Paris, Les éditions du Cerf, 2006, p.124, n.1. Arguments for an independent version are given by LIPPOLD, Ursinus und Damasus, p.110. Lippold considers Socrates' version worse in quality than that of Jerome and Rufinus.

${ }^{23}$ See Guy SAbBah, André-Jean Festugière \& Bernard Grillet (ed.), Sozomène. Histoire Ecclésiastique. Livres V-VI (SC, 495), Paris, Les éditions du Cerf, 2005, p.351-353.

${ }^{24}$ See e.g. LipPOLD, Ursinus und Damasus, p.109; LÖX, Monumenta sanctorum, p.25-26; and L. CRACCO RUGGINI, Clientele e violenze urbane a Roma tra IV e VI secolo, in R. SORACI (ed.), Corruzione, repressione e rivolta morale nella Tarda Antichità, Atti del Convegno Internazionale (Catania, 11-13 dic. 1995), Catania, 1999, 7-52, p.33, n.60.
} 
Ammianus Marcellinus was a non-Christian historian of the late fourth century, whose Res gestae record the history of the Roman emperors from the year 96 to the death of the emperor Valens in 378. Damasus and Ursinus figure in the accounts of the years 367 and 368, where Ammianus provides an extensive description of the disputed election. The only thing he says about the cause of the conflict, however, is that it was about who should be the new bishop of Rome. Ammianus records the clash between the different groups, the number of victims, the place of the massacre, and the attitude of the city prefect Viventius. The nature of Ammianus's report and its level of detail differ greatly from the Gesta 25 .

Although some scholars have cast doubt on his impartiality, Ammianus writes from an outsider's perspective and is therefore likely to have been neutral about church-political matters, without choosing sides as to who was the rightful new bishop of Rome ${ }^{26}$.

The Liber Pontificalis is a collection of notes about the bishops of Rome, from Peter up to Stephen V (885-886). The oldest edition, which dates to the early sixth century, does not address the disputed succession of Liberius. That succession is mentioned, however, in the second edition, which dates to the mid-sixth century, and upon which our current standard text is based $^{27}$.

Assessing the reliability of the Liber Pontificalis, D. Trout writes: "The ultimate question for historians, of course, concerns the reliability of the Liber. [...] Despite that suspect beginning [a forged correspondence between Jerome and Damasus on the design of the work], it is now generally agreed that the Liber Pontificalis preserves a significant amount of trustworthy material. This is especially true of, but not limited to, the archival portions of the lives (e.g. donation lists and ordination accounts). Nevertheless, all material in the text

\footnotetext{
25 As described by LIZZI TESTA, Senatori, popolo, papi, p.153-154, n.203. In addition, and in contrast to the communis opinio, Lizzi Testa assumes that it was Ammianus's intention to present an ideal situation for a city prefect such as Viventius, and that the description of the bloody clash at the basilica Sicinini only serves to introduce Ammianus's criticism of urban luxury among the clergy compared to the sober life of their colleagues in the countryside.

${ }^{26}$ Ammianus's neutrality is posited by GHILARDI, Tempore quo gladius, p.180, n.208, who, with Edward Gibbon, finds Ammianus "an accurate and faithful guide", REUTTER, Damasus, Bischof von Rom, p.42; and LIPPOLD, Ursinus und Damasus, p.110. For doubts on his impartiality, see e.g. A. CoşKUN, Der Praefect Maximinus, der Jude Isaak und der Strafprozess gegen Bischof Damasus von Rom, in Jabrbuch für Antike und Christentum 46 (2003) 17-44, p.21, n.13. Coşkun takes a position against Dattrino's assertion (L. DATTRINO, Papa Damaso, p.150) that Ammianus defended Ursinus and Künzle's that Ammianus's account was hostile to Damasus (P. KÜNZLE, Zur basilica Liberiana: basilica Sicinini = basilica Liberii, in RömQS 56 (1961) 1-61, 12966, p.130 sqq.). Mentioning Lippold's emphasis on Ammianus' neutrality (A. LIPPOLD, Ursinus und Damasus, p.110), Coşkun agrees with Neri (V. NERI, Ammiano e il cristianesimo. Religione e politica nelle "Res gestae" di Ammiano Marcellino, Bologna, CLUEB, 1985, p.200 sqq.) that Ammianus follows a Damasus-friendly tradition by approving of Ursinus's exile; Cosskun further posits that Ammianus's real agenda was to defend the city prefect Praetextatus.

${ }^{27}$ For a comparison of the texts about Damasus in the various editions and redactions, see A. FERRUA, Epigrammata Damasiana, Città del Vaticano, Pontificio Istituto di Archeologia Cristiana, 1942, p.59-60. A good overview of L. Duchesne's theory of the different editions of the Liber Pontificalis is given in BLAIRDIXON, Memory and authority, p.65-66.
} 
requires careful consideration before it can be used as 'evidence" "28. Scholars point to the different historical value of the subsequent redactions of the Liber Pontificalis ${ }^{29}$, with most preferring the older redactions, which of course do not contain the account of the conflict between Damasus and Ursinus.

Comparing the Liber Pontificalis with the Collectio Avellana, we can observe in both a tendency to present all periods of the papacy in sixth-century terms, a desire to defend the papal cause against political pressure, as well as a concern for defining and defending the papacy on the basis of document collections or archives. Despite these similarities, the two collections present or draw on different documents and each collection expresses a different point of view. The sixth-century redaction of the Liber Pontificalis presents a Damasus-friendly view of the conflict ${ }^{30}$. It has been suggested that "if the Liber Pontificalis and the Collectio Avellana are read in light of each other, then the contrasting strategies of each text with regard to the problem of authority and memory will allow us to correct, at least in part, for their often ignored distortions" 31.

\section{CRITERIA FOR A VALID SUCCESSION}

In the following section, and based on the partial information that has come down to us through the different documents, we examine which of the contenders, Damasus or Ursinus, had the better claim to be the rightful successor of Liberius. An important task is therefore to establish the criteria that determined valid episcopal succession in the Eternal City.

Beside the disputed election between Damasus and Ursinus, Rome has known other dual elections and other conflicts over episcopal succession. These episodes may shed light on the conflict between Damasus and Ursinus.

For example, issues similar to those at play in the dispute concerning the successor of Liberius were present in a parallel situation in 418, when the archdeacon Eulalius and the priest Bonifatius competed to succeed Zosimus. A short overview of the facts is as follows: both Eulalius and Bonifatius were elected and ordained. Upon notice by the city prefect, the emperor approved Eulalius; this approval was later withdrawn at the request of the supporters of Bonifatius. The emperor then called a local synod in Ravenna to solve the problem. When the local synod did not resolve the issue, the emperor convened a national Italian synod. Meanwhile both rivals were forbidden to enter Rome. Eulalius violated this ban, with the result that the emperor recognized Bonifatius as the lawful successor to

\footnotetext{
${ }^{28}$ D. Trout, Damasus of Rome, p.60, with reference to the papers in H. GEERTMAN (ed.), Atti del colloquio internazionale: Il Liber Pontificalis e la storia materiale. 21-22 febbraio 2002, Rome, Netherlands Institute in Rome, 2002.

29 Thus LIZZI TESTA, p.171, n.272. On the other hand, the later texts, which were written contemporaneously with the pontificate discussed, offer a better guarantee of truthfulnees. See Michel AUBRUN, Le livre des papes. Liber pontificalis, Turnhout, Brepols, 2007, p.7, n.1.

30 Writes L. CRACCO RUGGINI, Clientele e violenze urbane, p.31, n.57.

${ }^{31}$ BLAIR-DIXON, Memory and authority, p.60, see also p.66 and p.74-76.
} 
Zosimus. The events are reported in the imperial correspondence contained in the Collectio Avellana.

By studying the events that led to the succession of Bonifatius, with particular attention to the letter addressed to the emperors by Bonifatius's supporters (Coll. Av. 17), M. Raimondi has been able to establish the following succession procedure: 1) assembly of the clergy together with the people; 2) election of the candidate by the clerics; 3) presentation of the choice to the people; 4) election of the candidate by the people through acclamation; 5) ordination of the new bishop; 6) recognition (subscriptio) of the new candidate by the priests; 7) benediction (blessing) by the bishops present; 8) procession of the new bishop ${ }^{32}$.

Based on this same letter, and on the correspondence between the emperor Honorius and the urban prefect Symmachus, G. Dunn lists the following elements as the criteria by which Eulalius had at first been considered the new and valid bishop of Rome: "the competent number of ordainers", "the right time and place for ordination", and "the fact that Eulalius was elected first". Conversely, again based on the above-mentioned Coll. Av. 17, G. Dunn also identifies arguments against the regularity of Eulalius's election : "his support [was] minimal" and he was ordained by a bishop who "was elderly and sick". An argument in favor of Bonifatius is that he "had the backing of seventy of Rome's presbyters". Eulalius, for his part, was "ordained by the bishop of Ostia, as custom required". Scrutinizing the phases of this conflict, Dunn observes: "Their conflict action was mild initially: the election of a leader, his ordination as bishop, the occupation of a basilica." Regarding "the arguments we see eventually about what made someone the legitimate bishop," Dunn reaches the following conclusion: "In Rome this had to do with the number of presbyteral and diaconal electors each candidate could muster, about who was elected first, and about the number of ordaining bishops (and the presence of the bishop of Ostia as the principal prelate)" 33 .

Likewise, R. Lizzi Testa, assessing the arguments used in the Gesta to promote Ursinus and to discredit Damasus, identifies several criteria, which the Gesta of course intends to favor Ursinus. Contributing to the validity of a succession are chronological precedence of ordination and being ordained in the right location; discrediting are the occurrence of violence or the use of illegal measures during the process of succession ${ }^{34}$.

Studying why Gregory became pope in 590, J. Moorhead identifies the following factors as beneficial to becoming the next bishop of Rome: membership in the diaconal college, being designated as successor by the previous pope, and diplomatic experience. Other factors were the family background of the candidate, or intervention by the public authorities ${ }^{35}$. In the following section we study how the criteria identified above applied to the papal election of 366.

\footnotetext{
32 See RAIMONDI, Elezione iudicio Dei, p.198-199.

${ }^{33}$ G. DunN, Imperial Intervention in the Disputed Roman Episcopal Election of 418/419, in Journal of Religious History 39 (2015) 1-13, p.4 \& p.10.

${ }^{34}$ See LIZZI TESTA, Senatori, popolo, papi, p.144.

35 See J. MoOrHeAD, On Becoming Pope in Late Antiquity, in Journal of Religious History 30 (2006) 279-293.
} 


\section{THE SUCCESSOR OF LIBERIUS}

\subsection{Diaconal background of the candidates}

In late antiquity, in addition to being designated by the previous bishop as his intended successor, a background as deacon, and certainly as archdeacon, was often an asset for becoming the new bishop of Rome ${ }^{36}$.

Several times the Gesta attach particular importance to the qualifications of deacon or archdeacon, e.g., in Coll. $A v$. 1, 2, where the qualification of diaconus is mentioned explicitly for Damasus and the qualification of archidiaconus for Felix; in Coll. Av. 1, 5, where Ursinus and two other deacons are mentioned by name as part of the group requesting the ordination of the deacon Ursinus as successor to Liberius; in Coll. Av. 1, 6, where two other deacons of the Ursinian camp are exiled; and in Coll. Av. 1, 10, which names the three Ursinian deacons allowed to return from exile ${ }^{37}$. In Coll. Av. 1,2 and Coll. Av. 1,5, the special qualifications of diaconus or archidiaconus are referred to in direct connection with episcopal ordination ${ }^{38}$. Indeed, Rome was in a special situation with regard to the diaconal college since the number of deacons was restricted to seven ${ }^{39}$. The restriction naturally afforded the diaconal college a special status ${ }^{40}$. The deacons were directly attached to the bishop and chose an archdeacon as their leader ${ }^{41}$. The college of deacons influenced episcopal elections

\footnotetext{
${ }^{36}$ See MoOrHead, On Becoming Pope, p.284 \& p.290.

${ }^{37}$ Coll. Av. 1, 2: "Clerus omnis id est presbyteri et archidiaconus Felix et ipse Damasus diaconus et cuncta ecclesiae officia omnes", and "[clerus] Felicem archidiaconum ordinatum in loco Liberii episcopum susceperunt". Coll. Av. 1, 5: "Tunc presbyteri et diacones Ursinus Amantius et Lupus cum plebe sancta, quae Liberio fidem seruauerat in exilio constituto, coeperunt ... sibi Ursinum diaconum pontificem in loco Liberii ordinari deposcunt". The reference to Damasus that follows does not describe him as a deacon but does attribute to him the ambition to become bishop in the place of Felix: "periuri uero in Lucinis Damasum sibi episcopum in loco Felicis expostulant". Coll. Av. 1, 6: "Ursinus [...] pontifex ordinatus, cum Amantio et Lupo diaconibus in exilium mitteretur". Coll. Av. 1, 10: "Tunc Ursinus cum Amantio et Lupo diaconibus septimo decimo Kalendarum Octobrium Lupicino et Iouino conss. ad urbem rediit". Here no qualification for Ursinus is given; in the eyes of the Gesta, he is the legitimate bishop at this moment.

${ }^{38}$ Coll. Av. 1, 2: "Sed clerus contra fas [...] Felicem archidiaconum ordinatum in loco Liberii episcopum susceperunt". Coll. Av. 1, 5: "Sibi Ursinum diaconum pontificem in loco Liberii ordinari deposcunt".

${ }^{39}$ MoOrheAd, On Becoming Pope, p.286, referring to Eusebius Historia Ecclesiastica 6.43 (ed. GCS 2); and Sozomen, Historia Ecclesiastica 7.19 (ed. GCS NF 4). The same assessment was made by M. Raimondi (Elezione iudicio Dei, p.185), who based on this fact was able to reconstruct the diaconal college of 366. Raimondi also proposes a partial composition for the diaconal college of 355, just before Liberius' exile. 40 As observed by MOORHEAD, On Becoming Pope, p.286: "The small number in the diaconal college could be held to suggest that a particular dignity pertained to the rank of deacon at Rome. Such a perception would have been in accord with views which had been current within the Roman church around 400, when Jerome, a person with first-hand experience of practice in Rome, had been uneasy at the authority wielded by deacons there".

${ }^{41}$ On the attachment of the deacons to the bishop, see S. DIEFENBACH, Römische Erinnerungsräume. Heiligenmemoria und kollektive Identitäten im Rom des 3. bis 5. Jabrbunderts n. Chr (Millennium-Studien, 11), Berlin, De Gruyter, 2007, p.223. On the position and election of the archdeacon, MOORHEAD, On Becoming Pope, p.286, n.43 refers to Jerome, ep. 146.20. In addition to the occurrence of the term archdeacon referred to
} 
in Rome, often with the result that a deacon, typically the archdeacon, became the new bishop. The elevation of a deacon to episcopal rank was not in agreement with canon law of that time, but Rome was apparently not the only place where a deacon could become bishop $^{42}$.

In the election of 366, both candidates held diaconal rank, as is stated by the Gesta. In the sources, however, we miss an indication as to who was the archdeacon, or which candidate had been designated by the previous bishop Liberius as his successor. From the silence of the Gesta, with its tendency to highlight elements favorable to Ursinus and unfavorable to Damasus, we may assume that Ursinus was not the archdeacon. Damasus may have been the archdeacon, but the possibility is unproven. Felix was the archdeacon in 355; he was also responsible for a schism and died in 365. From Raimondi's reconstructions of the diaconal college in 355 and 366, we may deduce that Damasus had the highest seniority, but seniority was apparently no guarantee for becoming the new archdeacon, since the position was an elected one ${ }^{43}$. Disputes among the deacons during the last year of Liberius's pontificate may have prevented the election of a new archdeacon. In any case, for the election of 366 the college of deacons presented itself as a divided group without a real leader.

\subsection{Election}

A regular episcopal election requires support by a majority of the clergy ${ }^{44}$; so a successful candidate is one that obtains support from a majority of the electors. According to normal procedure, all electors convene at one place to vote for their preferred candidate. In the case of the parallel elections mentioned above, it is at this point that the problems arose. The candidates and their respective followers convened at different places, each obtaining, at a minimum, the support of a majority of the electors present at that location, hence not a majority of all the electors. The amount of support obtained was important; the place in which each election was held was in principle not, although it may hint at the nature of a particular candidate's support. With respect to the election, chronological precedence does seem to have played a decisive role ${ }^{45}$.

\subsubsection{Relative Chronology}

With respect to the election and ordination of both candidates in 366, chronological information is scarce. Therefore it is difficult to reconstruct the chronology of events

here and the occurrences in Collectio Avellana 1, 5, G. Dunn (Imperial Intervention, p.2, n.3) finds in Coll. Av. 17.2 one of the earliest references to this position among the Roman deacons.

42 As MOORHEAD relates in On Becoming Pope p.284-285. For the papal legislation, Moorhead refers to letters by Pope Siricius and Pope Zosimus.

43 See RAIMONDI, Elezione iudicio Dei, p.185 for the composition of the diaconal college and MOORHEAD, On Becoming Pope, p.286, n.43 for the special position of the archdeacon.

${ }^{44}$ See DUNN, Imperial Intervention, p.4.

45 For this, see for instance the above mentioned election of 418, where Eulalius was elected first but Bonifatius finally became the bishop of Rome. 
relating to the conflict between Damasus and Ursinus in their race to become, upon the death of Liberius in 366, the next bishop of Rome ${ }^{46}$. Many sources restrict themselves to asserting the precedence of one candidate's election or ordination over that of the other; other sources do not give any chronological information at all. The only detailed source is the Gesta, but even there exact dates, though provided for other events, are absent for events associated with the conflict between Ursinus and Damasus ${ }^{47}$. Hence the sequence given by the Gesta for the elections and ordinations of Ursinus and Damasus is at best only a relative one ${ }^{48}$. Other sources provide very little precise chronological information: Ammianus and Sozomen provide none; Jerome, Rufinus, and Socrates only imply the priority of Damasus's ordination. The divergent information from these sources proves difficult to reconcile ${ }^{49}$. A sound assumption seems to be that the two candidates were elected almost at the same moment ${ }^{50}$.

\subsubsection{Place of election}

In the later dispute of 418, Eulalius was elected in the Lateran basilica, Bonifatius in the Church of Theodora ${ }^{51}$. From this diversity of locations we may deduce that there was no fixed place for the election of the new Roman bishop. The most detailed topographical information about the competition between Damasus and Ursinus to succeed Liberius may be found in the Gesta. This document is also the only one to mention the place of the election of Ursinus and the place of the nomination of Damasus.

\subsubsection{In Lucinis}

According to the Gesta, the desire of Damasus's supporters to see him as the new bishop was expressed in a place called 'Lucina', in Lucinis ${ }^{52}$. The event referred to was not a formal election; instead Damasus was merely nominated at that place to be a candidate ${ }^{53}$. The

\footnotetext{
${ }^{46}$ DIEFENBACH agrees in his Römische Erinnerungsräume, p.226, n.38.

47 The Gesta (Coll. Av. 1) provide exact dates for the deaths of Felix (22 November 365) and Liberius (24 September 366), for the start of the clash at the basilica Liberii (26 October 366, 8 a.m.), for the return of Ursinus and his two deacons from exile (15 March 367), and for the second exile of Ursinus, beginning on 16 November 367. Relative information about chronology includes the three-day duration of the initial confrontation at the basilica Iulii and Damasus's occupation of the basilica Lateranensis as well as his ordination there seven days later.

48 As ReUTTER observes in Damasus, Bischof von Rom, p.36.

${ }^{49}$ As REUTTER again notes in Damasus, Bischof von Rom, p.47 : "Stimmt die Chronologie des Ursinerberichts, verschweigen alle anderen Quellen, daß Ursinus bereits zum Exil verurteilt wurde, oder Hieronymus, Rufin und Ammian berichten nur von den Auseinandersetzungen, die der Ursinerbericht als die an der basilica Iuli darstellt, d.h. vor der Ordination des Damasus; dann wäre die Chronologie, die die beiden kirchlichen Schriftsteller bieten, falsch".

${ }^{50}$ Cf. DiefenBACH, Römische Erinnerungsräume, p.225; and LiPPOLD, Ursinus und Damasus, p.113. See also REUTTER, Damasus, Bischofvon Rom, p.43 and p.136, n.37. Reutter, based on the exact wording and the silence of the Gesta as to certain details, deduced that it was most likely not Ursinus but Damasus who was elected first.

${ }^{51}$ Discussed by DunN, Imperial Intervention, p.1-2.

${ }^{52}$ Coll. Av. 1,5: "Periuri uero in Lucinis Damasum sibi episcopum in loco Felicis expostulant".

${ }^{53}$ GHILARDI, Tempore quo gladius, p.174, n.195; DE SPIRITO, Ursino e Damaso, p.266; and RAIMONDI, Elezione iudicio dei $e$ turpe convicium, p.200-20, argue that this was not the real election, but only an expostulatio, a nomination of Damasus.
} 
location mentioned refers to a titular church designated by the name in Lucinis ${ }^{54}$. Although it has been thought that this name corresponds to the building later known as the Church of San Lorenzo in Lucina ${ }^{55}$, archaeological evidence does not support this thesis ${ }^{56}$. Therefore it is more logical that the designation refers to another church in the same area, namely, the titulus beati Marcelli as argued by R. Lizzi Testa. That area was home to Damasus and an ideal place for him to obtain support; it was in the same area he converted his family domus into the titular church that later would receive the name San Lorenzo in Damaso ${ }^{57}$.

\subsubsection{Basilica Iulii}

The Gesta mention that Ursinus was elected in the basilica Iulii ${ }^{58}$. A consensus has not yet been reached about the identity of the church referred to by this name ${ }^{59}$. According to the Liber Pontificalis, pope Julius I (pontificate: 337-352) had built two churches that took his name, one in Trastevere, the other close to Trajan's forum ${ }^{60}$. Earlier in the Gesta, '<basilica> Iuli' is mentioned in combination with the clarification 'trans Tiberim';' 61 this has led some scholars to identify the basilica Iulii with the current Santa Maria in Trastevere ${ }^{62}$. Others have argued that the term 'basilica' was a later addition in Coll. Av. 1, $3^{63}$. In that case, the basilica Iulii in Coll. Av. 1,5 does not need to be in Trastevere, and it could therefore be identified with the basilica Iulii iuxta forum Traiani instead ${ }^{64}$. In addition to the argumentation given above, in Coll. Av. 1, 3 the Church of Julius in Trastevere has been linked to Felix. If Ursinus had been elected in this same church, it would have been unlikely for the Gesta - in keeping with its polemical strategy of putting Ursinus in the line of Liberius and Damasus in the

\footnotetext{
${ }^{54}$ See GHILARDI, Tempore quo gladius, p.182-183 and DE SPIRITO, Ursino e Damaso, p.266.

${ }_{55}$ D. Trout (Damasus of Rome, p.6) also calls the building "a basilical forerunner, it seems, of S. Lorenzo in Lucina near the Via Lata in the northern Campus Martius". Others directly identify in Lucinis with S. Lorenzo in Lucina, as noted by REUTTER, Damasus, Bischof von Rom, p.36, n.136.

56 As reported by BLAIR-DiXON, Memory and authority in sixth-century Rome, p.71-72: "With the exception of the Praefatio, literary references to the titulus Lucinae, as in the lists of 499, or to the basilica of S. Lorenzo in Lucina mentioned in LP, all date to the late fifth and sixth centuries. Recent excavations, however, have adequately demonstrated that the church did not exist until the early fifth century".

${ }^{57}$ LIZZI TESTA, Senatori, popolo, papi, p.146-147.

${ }^{58}$ Coll. Av. 1,5: "Tunc presbyteri et diacones Ursinus Amantius et Lupus cum plebe sancta, quae Liberio fidem seruauerat in exilio constituto, coeperunt in basilica Iuli procedere et sibi Ursinum diaconum pontificem in loco Liberii ordinari deposcunt".

${ }^{59} \mathrm{~A}$ good overview of the different positions and their arguments is given in GHILARDI, Tempore quo gladius, p.183-185; and in RAIMONDI, Elezione iudicio Dei, p.199, n.141.

${ }_{60}$ As reported by V. FIOCCHI NICOLAI, Strutture funerarie ed edifici di culto paleocristiani di Roma dal IV al VI secolo, Città del Vaticano, Pontificia Commissione di Archeologia Sacra, 2001, p.60.

${ }^{61}$ Coll. Av. 1,3: "Felix notatus a senatu uel populo de urbe propellitur. Et post parum temporis impulsu clericorum, qui peiurauerant, inrumpit in urbem et stationem in <basilica $>$ Iuli trans Tiberim dare praesumit".

${ }^{62}$ Proponents of this view are listed by ReUTTER Damasus, Bischof von Rom, p.35, n.135. Cf. Trout, Damasus of Rome, p.5-6.

${ }^{63}$ LIZZI TESTA, Senatori, popolo, papi, p.137, n.151: “<Basilica> è inserzione dell'editore Günther [App. crit., p.2] in base alla notizia di L. P. 36, ove si afferma che papa Giulio costruì due basiliche intramurane, e per il fatto che poco oltre nel testo [C. A. 1, 5, 20-21] si menziona la basilica Iulii come luogo ove fu eletto Ursino".

${ }^{64}$ As argued by H. GeERTMAn, Hic fecit basilicam. Studi sul Liber Pontificalis e gli edifici ecclesiastici di Roma da Silvestro a Silverio, Leuven, Peeters, 2004, p.240.
} 
line of the schismatic Felix - to have mentioned this detail instead of keeping it silent. Therefore the most likely location for the election of Ursinus is the basilica Iuli iuxta forum Traiani.

\subsubsection{Geographic implications}

So Ursinus was elected in the basilica Iulii, and Damasus became a candidate in the titulus in Lucinis. The terminology used in the Gesta to refer to Roman churches is of some interest here. For the three churches with episcopal dignity, the Gesta consistently use the term 'basilica'; the other churches are mentioned without this title and only with a name in the genitive ${ }^{65}$. When a church is named without a title, it is regularly a titular church (titulus) that is meant. Unlike the basilicas, which were under direct control of the bishop with assistance by the deacons ${ }^{66}$, titular churches had an aristocratic background and had often developed from private houses (domus); as a result, the titular churches were managed by the priests rather independently from the bishop ${ }^{67}$. This distinction was maintained later in the Lenten stational liturgy, during which the more significant stationes on Sundays and important weekdays were assigned to the basilicas, and the ceremonies on the other weekdays were held in the titular churches ${ }^{68}$.

Efforts have been made based on the geographical data to outline the groups that supported either candidate. With the election of Damasus happening in a titular church, 'in Lucinis', and that of Ursinus in the basilica Iulii, a logical deduction would be that Damasus had the support of priests and the rich aristocracy, while Ursinus was backed by the plebs and the clergy who were under control of the bishop ${ }^{69}$. Later investigations, which have assumed that both candidates had the support of part of the aristocracy ${ }^{70}$, focus on which aristocratic group supported which candidate. In the relationship mentioned in the Gesta between

\footnotetext{
${ }^{65}$ See GeERTMAn, Hic fecit basilicam, p.29-30: "A questo resoconto segue la vivace descrizione, del conflitto tra Damaso e Ursino (cc. 5-14) e le determinazioni topografiche nei passi citati sono: c. 3 stationem in Iuli trans Tiberim / c. 5 in basilica Iuli / in Lucinis / ad basilicam Iuli / c. 6 Lateranensem basilicam / ad basilicam Liberii / c. 9 in basilica Liberii / c. 12 ad sanctam Agnem / Queste sono tutte denominazioni di uso corrente nel linguaggio comune e supporre - come si è dato il caso - l'uso di un linguaggio denigratorio o corruzione del testo è del tutto superfluo" (backslash added to indicate new lines in the original text). See also DiEFENBACH, Römische Erinnerungsräume. Heiligenmemoria und kollektive Identitäten im Rom des 3. bis 5. Jahrbunderts n. Chr (Millennium-Studien, 11), Berlin, De Gruyter, 2007, p.232-233.

66 As noted by DIEFENBACH, Römische Erinnerungsräume, p.223.

${ }^{67}$ See LiZZI TESTA, Senatori, popolo, papi, p.95. and FIOCCHI NICOLAI, Strutture funerarie, p.93. The earlier opinion, however, that every titular church referred to a private house from before the freedom of religion, is no longer supportable. So FIOCCHI NICOLAI, Strutture funerarie, p.99.

${ }^{68}$ GEERTMAN, Hic fecit basilicam, p.18 sqq.; also DIEFENBACH, Römische Erinnerungsräume, p.233.

${ }^{69}$ See, for example, L. Cracco Ruggini (Rome in Late Antiquity, p.373-374), who in this way identifies aristocratic support for Damasus: "the final victory of Damasus [...] can be interpreted as that of an aristocratic faction, not even necessarily Christian, but in any case concerned to ensure the victory of a candidate to the papal throne whom they judged to be pliable and therefore desirable". And cf. S. Diefenbach (Römische Erinnerungsräume, p.233), who disagrees with the position put forward by Ruggini: "Die Differenzierung in einen felicianisch-damasianischen Titelklerus mit starkem Rückhalt in der Senatsaristokratie und in einen liberisch-ursinischen Bischofsklerus mit enger Beziehung zur plebs sancta kann also, was die Verhältnisse unter Liberius und Felix II. betrifft, nicht überzeugen".

${ }^{70}$ LiZZI TESTA, Senatori, popolo, papi, p.136.
} 
Ursinus and Liberius on the one hand and between Damasus and Felix on the other ${ }^{71}$, an indication has been found that Ursinus was supported by the "the great Christian senatorial families (Anicii-Probi, Valerii, Ambrosii) who were closely involved in the work of Christianization carried out by Pope Liberius among the senatorial class" 72 , whereas Damasus was supported by the newly converted families ${ }^{73}$. Noticing, however, the good relationship between Damasus and Ambrose, other scholars have considered the opposite to be more likely: it was Damasus who was supported by the old Christian families, and the dispute about the succession between Damasus and Ursinus was an element in a power struggle among the different aristocratic families in Rome to further their influence, including their influence in the Christian community ${ }^{74}$.

The geographical location of the churches involved in the dispute is instructive, though not because that location reflects a link between Damasus and Felix or between Ursinus and Liberius $^{75}$, and not because the location indicates support by the local aristocracy ${ }^{76}$. More important was the personal relationship of each candidate to the population of the specific area in which each was elected, whether that relationship was due to prior pastoral work there, or to existing family ties ${ }^{77}$.

For Damasus this link was clear, since in Lucinis was the place of his father's house; for Ursinus further investigation is required to establish such a relation between the place of

${ }^{71}$ Coll. Av. 1,5 [CSEL 35, 2]: "Periuri uero in Lucinis Damasum sibi episcopum in loco Felicis expostulant. $[\ldots]$ Tunc presbyteri et diacones Ursinus Amantius et Lupus cum plebe sancta, [...] sibi Ursinum diaconum pontificem in loco Liberii ordinari deposcunt".

72 RAIMONDI, Elezione iudicio Dei, p.172, with reference to LIZZI TESTA, Senatori, popolo, papi, p.143-170.

${ }^{73}$ See the description and demurral in DIEFENBACH, Römische Erinnerungsräume, p.236, n.75.

${ }^{74}$ Poglio, Gruppi di potere, p.159-160: "Si potrebbe ritenere che l'elezione di Damaso al soglio vescovile della città di Roma fosse il frutto di un'alleanza dei casati cristiani, gravitanti attorno ai Probi-Anicii, con i pagani Ceionii-Rufii, capeggiati da Volusianus Lampadius i quali, nell'occasione, agirono di conserva". Poglio (p.156, n.240) criticizes Lizzi Testa's point of view, basing his argument on the link between Ambrose and Damasus; Poglio therefore does not accept, rightly in our view, that Ursinus was supported by a family alliance with the Ambrosii. In Poglio's view, the confrontation between Ursinus and Damasus for the see of Rome was part of the struggle for influence and power between the established families of the Roman upper class. The thread in Poglio's work is the change in power dynamics in the city of Rome, in the provinces, and in the wider Roman Empire during the second half of the fourth century, when the different senatorial or aristocratic clans managed to establish their power and influence at the expense of the opposing families and their alliances. Poglio's concludes that the greater part of the second half of the fourth century was characterized by continuous struggles between aristocratic families. On the one hand, there were the families of pagan denomination, like the Vulcacii-Nazeratii, Orfiti, Symmachi, Nicomachi and Praetextati. They opposed the Christianized aristocratic families, like the Probi-Anicii, the Gracchi, the Furii, the Paulini, the Bassi, the Valerii, and the Ambrosii (with the Ceionii-Rufii family, still largely pagan in its lifestyle, associated with the latter). These struggles between aristractic families had repercussions for the conflict between Damasus and Ursinus as well.

75 The Gesta promote the connection between Damasus and Felix in order to portray Damasus in a bad light. From an anti-Damasus source, this portrayal loses its value, as explained by DIEFENBACH, Römische Erinnerungsräume, p.237, n.75.

${ }^{76}$ L. Cracco Ruggini (Rome in Late Antiquity, p.373-376) located the titulus in Lucinis, where Damasus was elected, in Trastevere, since that was a traditionally Christian area and the area where traditional rich aristocratic families had their private houses (domus). However, the idea of locating the titulus in Lucinis in Trastevere has proved to be untenable, as stated by DIEFENBACH, Römische Erinnerungsräume, p.235, n.69.

77 As LIZZI TESTA, Senatori, popolo, papi, p.136, explains. 
his election and the people that supported him. With the election in the basilica Iulii by his followers, Ursinus made the first step towards succeeding Liberius. Damasus had merely been appointed by his supporters to be the successor of Liberius; further steps needed to be taken in order to consolidate his candidacy and prevent Ursinus's. Inevitably the two groups confronted each other. As to what happened next, we have no account other than that of the Gesta: a three-day clash at the basilica Iulii, with casualties ${ }^{78}$.

\subsection{Episcopal ordination}

A valid ordination requires a "competent number of ordainers" and "the right time and place for ordination". The competence of the ordainers could be questioned, for example, when the ordaining bishop "was elderly and sick". ${ }^{79}$

A traditional framework for the consecration of a new bishop of Rome has been identified by Ch. Pietri: the consecration, or ordination, took place in the Lateran basilica, on a Sunday, and the consecration was performed by the bishop of Ostia. For the place of consecration, Pietri gives as examples the location of Damasus's consecration (Coll. Av. 1.6) and that of Eulalius's (Coll. Av. 14,4); for occurrence on a Sunday, he refers to the cases of Damasus, Bonifatius, and Celestinus, and maybe of Siricius; the role of the bishop of Ostia is attested by Augustine of Hippo ${ }^{80}$.

\subsubsection{Place of ordination}

In 418, during the dispute as to who would succeed Zosimus, Eulalius was ordained bishop in the Lateran basilica, where he had been elected two days before; Bonifatius was ordained bishop in San Lorenzo in Lucina, not in the Church of Theodora, where his election had taken place the day before ${ }^{81}$. Both managed to be recognized as bishop of Rome, which means that both churches were valid locations for an ordination ${ }^{82}$.

\footnotetext{
${ }^{78}$ Coll. Av. 1,5: "Quod ubi Damasus, qui semper episcopatum ambierat, comperit, omnes quadrigarios et imperitam multitudinem pretio concitat et armatus fustibus ad basilicam Iuli perrumpit et magna fidelium caede per triduum debacchatus est".

${ }^{79}$ DUNN, Imperial Intervention, p.4, quoted above.

${ }^{80}$ Charles PIETRI, Roma christiana: Recherches sur l'Eglise de Rome, son organisation, sa politique, son idéologie de Miltiade à Sixte III (311 - 440) (Bibliothèque des écoles françaises d'Athènes et de Rome, 224), Rome, École française de Rome, 1976, p.681-682: “En revanche, l’Eglise romaine a pu fixer, dès la fin du IVe siècle, le cadre de la consécration: la cérémonie se déroule au Latran [note 6, which refers to Damasus (Coll. Av. 1,6) and Eulalius (Coll. Av. 14,4)], dans la basilique de la liturgie pontificale, et suivant une habitude ancienne, un dimanche [note 7, which refers to the term 'dies consuetus' in Coll. Av. 14,4 and 15,1 and states that verification is possible for Damasus, Bonifatius, and Celestinus, and maybe for Siricius; the note also refers to Michels (1925) and Lietzman]. Une autre tradition s'impose définitivement; elle attribue à l'évêque d'Ostie, la consécration de l'élu [note 1, with reference to the Liber Pontificalis and to Augustine, Brev. Coll. 3,16)]. Le Liber Pontificalis faisait remonter cette pratique au pape Marc; Augustin en donne sûrement témoignage pour la fin du IVe siècle".

${ }^{81}$ DUNN, Imperial Intervention, p.2.

${ }^{82}$ DIEFENBACH, Römische Erinnerungsräume, p.250, n.126.
} 


\subsubsection{Basilica Lateranensis}

Damasus was ordained in the Lateran basilica ${ }^{83}$, which, as the church of the Roman bishop and the see of his administration, was a location of considerable importance ${ }^{84}$. Its suitability for the ceremony ${ }^{85}$, was augmented by its location in the center of Rome and its foundation by the emperor Constantine ${ }^{86}$. U. Reutter finds in the location of Damasus's ordination there an argument in favor of the legitimacy of Damasus's installation process ${ }^{87}$. M. Raimondi sees in the Gesta's report about this place an indication that the Ursinians also recognized its importance 8 . Similarly, that the Gesta mention the basilica Lateranensis as the place of Damasus's ordination, instead of hiding this detail, is for S. Diefenbach and A. Lippold an indication that the basilica Lateranensis was not seen as the only legitimate location for an episcopal consecration ${ }^{89}$. The Lateran basilica certainly was a traditional place for an episcopal ordination, but it was not the only valid location.

Significant too is the absence of violence at the basilica Lateranensis ${ }^{90}$. Damasus seems to have taken possession of this basilica without resorting to force, and he was able to hold it against the Ursinians. The latter probably tried to disturb Damasus's installation ceremony, just as Damasus's followers disturbed the installation ceremony of Ursinus at the basilica Iulii. Intervention of public forces likely prevented such a disturbance on the part of the Ursinians and, by detaining the Ursinian priests, facilitated Damasus's ordination. By mentioning the liberation of these seven Ursinian priests by the partisans of Ursinus, Coll. Av. 1,6 alludes to their prior detention ${ }^{91}$.

\subsubsection{Basilica Liberii or Sicinini}

Most scholars who have examined the issue think Ursinus was ordained in the basilica Iulii immediately after his election in the same location" ${ }^{92}$. This claim is based on the text of the Collectio Avellana; at Coll. Av. 1,5 the 'ordination' of Ursinus by bishop Paul of Tivoli is mentioned immediately after Ursinus's election and before Damasus's ordination, while Coll. Av. 1,6, indicates that Ursinus was ordained before Damasus. The text of the Gesta, however, is not very clear ${ }^{93}$. Given that the text of the Gesta uses the word benedictus instead of ordinatus, and that historians such as Jerome, Rufinus, and Socrates do not place Ursinus's consecration in the basilica Iulii, but elsewhere, namely, in the area Sicinini or the basilica

\footnotetext{
83 This location is mentioned in the Gesta (Coll. Av. 1,7): "Lateranensem basilicam tenuit et ibi ordinatus episcopus". Though not confirmed by other ancient sources, the location is taken for fact by modern authors, e.g., TROUT, Damasus of Rome, p.6; and REUTTER, Damasus, Bischof von Rom, p.44.

${ }^{84}$ See REUTTER, Damasus, Bischof von Rom, p.44; and PIETRI, Roma christiana, p.411-412.

85 So RAIMONDI, Elezione iudicio Dei, p.202.

86 See DIEFENBACH, Römische Erinnerungsräume, p.230; and FIOCCHI NiCOLAI, Strutture funerarie, p.52.

${ }^{87}$ REUTTER, Damasus, Bischof von Rom, p.44: "Darauf [der reguläre Vorgang für die Einsetzung eines neuen Bischofs] deutet auch die Ordination des Damasus in der Lateransbasilika hin, die zu dieser Zeit die Kirche des römischen Bischofs und sein Amtssitz war; deshalb sprechen auch Hieronymus und Rufinus von einer Priorität der Damasusordination".

88 RAIMONDI, Elezione iudicio Dei, p.200.

${ }^{89}$ See DIEFENBACH, Römische Erinnerungsräume, p.231 and LIPPOLD, Ursinus und Damasus, p.119.

${ }^{90}$ See RAIMONDI, Elezione iudicio Dei, p.202.

${ }^{91}$ See LIZZI TESTA, Senatori, popolo, papi, p.152.

92 See DE SPIRITO, Ursino e Damaso, p.266.

93 See the remarks of LIPPOLD, Ursinus und Damasus, p.114-115.
} 
Sicinini, the hypothesis that Ursinus was ordained elsewhere, possibly in secret ${ }^{94}$, deserves consideration.

Coll. Av. 1, 5 reports that the process of Ursinus's installation at the basilica Iulii was interrupted: Damasus and his supporters invaded the church, and a violent clash with bloodshed followed ${ }^{95}$. Ursinus and his followers were apparently driven from that location. After having been forced to abandon the basilica Iulii, Ursinus had to look for another place in which to continue the ordination. With only three basilicas in the city center suitable for episcopal ordinations and since Ursinus had just been driven out of the basilica Iulii, and since Damasus was occupying the basilica Lateranensis, the only choice left to Ursinus was the basilica Liberii. When Damasus occupied the basilica Lateranensis in support of his claim to the see, "the Ursinians countered this occupation of the bishop's church, which had been founded by Constantine, with the basilica Liberii, a central location that seems to have possessed a rank comparable to that of the bishop's church"96. The basilica Liberii is also mentioned in Coll. Av. 1,7, where it is the location of a violent clash between the partisans of Ursinus and of Damasus. This clash resulted in 160 Ursinians killed, more injured, and serious damage to the building: its main doors were damaged by fire and broken open; roof tiles were thrown down; and the roof itself was destroyed ${ }^{97}$. A violent confrontation between Damasus and Ursinus is also reported by Ammianus, along with the exact number of 137 casualties on the rebel side; Ammianus identifies the basilica Sicinini as the location of this confrontation ${ }^{98}$. Some scholars have regarded this confrontation as the same event

\footnotetext{
${ }_{94}$ An indication in favour of such a secret ordination is that, apart from Bishop Paul of Tivoli giving his blessing to Ursinus (Coll. Av. 1,5), no ordaining bishop is mentioned in Coll. Av. 1. Sozomen's account of Ursinus's ordination (Hist. Ekkl. VI, 23, 1-3) points in the same direction: "A deacon named Ursicius [Ursinus], who had obtained some votes in his favor, but could not endure the defeat, therefore caused himself to be clandestinely ordained by some bishops of little note". English translation from Ph. SCHAFF \& H. WACE (ed.), A select Library of Nicene and Post-Nicene Fathers of the Christian Church; Second Series. Volume II. Socrates, Sozomenus: Church Histories, Edinburg, T\&T Clark; Grand Rapids, MI, Eerdmans, 1989, p.359.

${ }^{25}$ Coll. Av. 1,5: "Ursinum Paulus Tiburtinus episcopus benedicit. Quod ubi Damasus, qui semper episcopatum ambierat, comperit, omnes quadrigarios et imperitam multitudinem pretio concitat et armatus fustibus ad basilicam Iuli perrumpit et magna fidelium caede per triduum debacchatus est".

${ }_{96}$ DiefenBACH, Römische Erinnerungsräume, p.229-230. According to Diefenbach (p.233-234), in fourthcentury Rome there were already three churches of episcopal rank: the Lateran basilica, the basilica Liberii, and the basilica Iulii. For both parties, Damasus and Ursinus, it was important to occupy a building in the city center in order to substantiate their claims. Another argument (p.231) in favor of one of these churches would have been the church's size and its location in a densely populated area of the city.

${ }^{97}$ See Coll. $A v$. 1,7: "Tunc Damasus cum perfidis inuitat arenarios quadrigarios et fossores omnemque clerum cum securibus gladiis et fustibus et obsedit basilicam hora diei secunda septimo Kalendarum Nouembrium die Gratiano et Dagalaifo conss. et graue proelium concitauit. Nam effractis foribus igneque subposito aditum, unde inrumperet, exquirebat; nonnulli quoque de familiaribus eius tectum basilicae destruentes tegulis fidelem populum perimebant. Tunc uniuersi Damasiani irruentes in basilicam centum sexaginta de plebe tam uiros quam mulieres occiderunt; uulnerauerunt etiam quam plurimos, ex quibus multi defuncti sunt. De parte uero Damasi nullus est mortuus".

98 Ammianus Marcellinus, Res Gestae, 27, 3, 13: "Constat que in basilica Sicinini, ubi ritus Christiani est conuenticulum, uno die centum triginta septem reperta cadauera peremptorum efferatam que diu plebem aegre postea delenitam". The term basilica Sicinini probably derives from administrative language, corresponding to Ammianus's objective to describe the events from the perspective of the Roman administration, cf. DIEFENBACH, Römische Erinnerungsräume, p.226, n.39.
} 
reported in Coll. Av. 1,7, leading to the conclusion that the basilica Sicinini and the basilica Liberii were one and the same place ${ }^{99}$. The two names referring to one basilica would be consistent with Jerome, Rufinus, and Socrates mentioning this place as the location of Ursinus's consecration (so Jerome and Socrates) or as the place of the deadly confrontation (so Ammianus and Jerome) ${ }^{100}$.

In this incident, the authorities did not intervene; in fact the city prefect Viventius withdrew from the scene ${ }^{101}$. But on other occasions, the authorities did take action. Ursinus was banished a first time shortly after the confrontations commenced (Coll. Av. 1, 6). The emperor later rescinded this decision and permitted Ursinus to return, possibly at the behest of Ursinus's followers (Coll. Av. 1, 10 and Coll. Av. 5). As the riots recommenced or continued, Ursinus was banished a second time (Coll. Av. 7, Ammianus Marcellinus). According to Coll. $A v$. 6, Ursinus was exiled to Gaul on account of the continuous unrest that he caused. As the imperial letters explicitly state, both banishments were motivated by the authorities' desire to restore order in Rome. That Ursinus was the one exiled shows that the secular power regarded him as the instigator of the troubles.

The identification of the basilica Sicinini with the basilica Liberii has not been self-evident to all scholars ${ }^{102}$. Nevertheless, while different opinions have been defended ${ }^{103}$, today there seems to be a near consensus, still not accepted by all ${ }^{104}$, or only with reserve ${ }^{105}$, that the basilica Sicinini was the basilica Liberii, ${ }^{106}$ which is also the current S. Maria Maggiore ${ }^{107}$. In addition, scholars have investigated the meaning of the term 'Sicininum'; it appears to refer to a zone or district in Rome, probably on the Esquiline ${ }^{108}$. So in Rome there was a district

\footnotetext{
${ }^{99}$ LiZZI TeSTA, Senatori, popolo, papi, p.153, n.203: "Le cifre dei due racconti non coincidono: 160 uccisi e una gran quantità di feriti, molti dei quali successivamenti defunti, secondo i Gesta; 137 cadaveri per Ammiano. È difficile tuttavia pensare che non si riferiscano ad uno stesso episodio, nella medesima basilica". 100 See Jerome, Chron. ad a. 366: "Romanae ecclesiae xxxu ordinatur episcopus Damasus et post non multum temporis interuallum ursinus a quibusdam episcopus constitutus sicininum cum suis inuadit, quo damasianae partis populo confluente crudelissimae interfectiones diuersi sexus perpetratae"; and RUFINUS, Hist. Eccl., 11, 10: "Vrsinus quidam eiusdem ecclesiae diaconus ... in basilica, quae Sicinini appellatur, episcopum se fieri extorqueret". Socrates (Hist. Ekkl., IV, 29, 1-6) also refers to this place: "A certain Ursinus, a deacon of that church, had been nominated among others when the election of a bishop took place; as Damasus was preferred, this Ursinus, unable to bear the disappointment of his hopes, held schismatic assemblies apart from the church, and even induced certain bishops of little distinction to ordain him in secret. This ordination was made, not in a church, but in a retired place called the Palace of Sicine, whereupon dissension arose among the people". English translation from Ph. SCHAFF \& H. WACE, Socrates, Sozomenus, p.113.

101 See Ammianus, Res Gestae, 27, 3, 12-13.

102 See ReUTTER, Damasus, Bischof von Rom, p.39; and LiPPOLD, Ursinus und Damasus, p.126.

103 See J. Curran, Pagan city and Christian capital. Rome in the fourth century (Oxford classical monographs). Oxford, Oxford university press, 2002, p.140.

104 As noted by LIZZI TESTA, Senatori, popolo, papi, p.154, n.204.

${ }^{105}$ See N. MCLYNN, Damasus of Rome. A fourth-century pope in context, in Therese FUHRER (ed.), Rom und Mailand in der Spätantike. Repräsentationen städtischer Räume in Literatur, Architektur und Kunst, Berlin - Boston, De Gruyter, 2011, 305-325, p.309.

${ }^{106}$ See DiEFENBACH, Römische Erinnerungsräume, p.227, n.39; and GEERTMAn, Hic fecit basilicam, p.29.

${ }^{107}$ See GEERTMAn, Hic fecit basilicam, p.26: "La basilica Liberii, per raggioni che non ci sono note, viene sostituita dalla nuova S. Maria Maggiore".

${ }^{108}$ See MCLynn, Damasus of Rome, p.309, n.30; and LiZZI TeSTA, Senatori, popolo, papi, p.154, n.204.
} 
called Sicininum, and all the old sources refer to this name as the location of a violent clash over the ordination of Ursinus; the Gesta alone speak about the basilica Liberii ${ }^{109}$.

Additionally, the term basilica Sicinini is used once in the Collectio Avellana. It occurs in the title of the sixth letter (Coll. Av. 6), in which the emperors command that the last church still in possession of the Ursinians be evacuated and given to Damasus ${ }^{110}$. Since this title probably stems from the official language of Roman administration, it employs a civil rather than a religious terminology ${ }^{111}$. This letter is dated after November 16th, 367 and before January 12 th, 368, so more than a year after the clash at the basilica Liberiil12. If the basilica Liberii had been surrendered by the party of Ursinus after the violent clash with the party of Damasus, identification of the basilica Sicinini with the basilica Liberii would be difficult ${ }^{113}$. An explanation may be that the Ursinians continued to occupy this basilica for more than a year after the bloodshed, even under pressure from the side of Damasus ${ }^{114}$. Coll. Av. 1,8 and Coll. Av. 1,9 seem to confirm such hypothesis ${ }^{115}$.

\subsubsection{Ordination day}

The transition process, from the death of a bishop to the election and ordination of his successor, could happen very fast. After Zosimus died on Thursday, December 26, 418, Eulalius was elected on the very next day, Friday the $27^{\text {th }}$, and Bonifatius was elected the day after that on Saturday the $28^{\text {th }}$. Both candidates were ordained on Sunday the $29^{\text {th }}$ of December ${ }^{116}$.

Concerning the chronology of the ordination of Damasus and Ursinus, information found in the different sources is contradictory; "witness stands against witness"117, and it is not the exact date that is stressed, but the precedence of one ordination before the other. Considering as incorrect the chronological information offered by Jerome, Rufinus, and Socrates ${ }^{118}$, and thus crediting the chronology found in the Gesta, some scholars have held

\footnotetext{
${ }^{109}$ K. Blair-Dixon (Memory and authority, p.71) sees in the term basilica Liberii an anachronism of the fifth or sixth century, that is, a later identification for a place previously known under a different name, or a reference to a building yet to be built. The insertion is due to a possible later interpolation or correction in the text.

110 As described by LIZZI TESTA, Senatori, popolo, papi, p.154, n.204.

111 See the explanation of DIEFENBACH, Römische Erinnerungsräume, p.228, n.44.

112 On the date of this letter, see TROUT, Damasus of Rome, p.7, n.28.

113 As assumed by CURRan, Pagan city, p.140.

114 See LizZI TESTA, Senatori, popolo, papi, p.159. Lizzi Testa disagrees with Curran that the Ursinians occupied more churches and that the last church to be evacuated by them, around one year later, was not the basilica Sicinini, but a different church; cf. CuRRAN, Pagan city, p.141.

${ }^{115}$ Coll. Av. 1,8: "Post tres autem dies sancta plebs in unum conueniens coepit aduersus eum domini mandata recitare" and Coll. Av. 1,9: "Saepe igitur eadem plebs adunata in basilica Liberii".

116 See DUNN, Imperial Intervention, p.1-2.

117 In the expression of REUTTER, Damasus, Bischof von Rom, p.43: "Hieronymus und Rufinus gehen davon aus, daß Damasus zuerst geweiht wurde, während der Ursinerbericht ausdrücklich davon spricht, daß die Weihe des Ursinus, die in der basilica Iuli stattfand, Priorität hatte und Damasus darauf mit einer dreitägigen Belagerung dieser basilica reagierte. Hier steht Zeugnis gegen Zeugnis".

118 So LiPPOLD, Ursinus und Damasus, p.109: "So ist bei Rufin die Chronologie von Wahl und Weihe der beiden Kontrahenten und auch die Angabe über den Ort der Weihe des Ursinus verfälscht".
} 
that Ursinus was ordained first ${ }^{119}$. Nevertheless, in view of the previously discussed accounts of Ursinus's ordination in the basilica Liberii, it seems more likely that Damasus was ordained first.

The traditional day of the week for an episcopal ordination was Sunday ${ }^{120}$, though not all scholars agree that this was a requirement at the time of the conflict between Damasus and Ursinus $^{121}$. The day that Liberius died, 24 September 366, was a Sunday. The next Sundays were 1 October and 8 October. That Damasus waited seven days before taking possession of the basilica Lateranensis for his ordination ${ }^{122}$, may indicate that he wanted to wait for the next available Sunday ${ }^{123} ; 1$ October was the first possible and is the most probable date for Damasus's ordination, with 8 October as a second possibility ${ }^{124}$. The biographical data provided in the Liber Pontificalis also point to October $1^{\text {st }}$ as the likeliest date for his ordination $^{125}$.

The Gesta give remarkably little information about the ordination of Ursinus. Apart from one mention in a concise sentence from Coll. Av. 1,5: "Ursinum Paulus Tiburtinus episcopus benedicit", the ordination is only referred to indirectly, once in Coll. $A v \cdot 1,5$ and once in Coll. $A v \cdot 1,6^{126}$. Noticeable is the difference in wording: 'ordinatus' for Damasus in Coll. Av. 1,6; 'ordinari' and 'ordinatus' for Ursinus in Coll. Av. 1,6; 'benedicit' in Coll. Av. 1.5, which might point to something special in Ursinus's ordination ${ }^{127}$. Except for the name of Bishop Paul of Tivoli, no further data are provided concerning Ursinus's ordination; even with regard to its exact date, we remain uninformed, which leaves us only to speculate.

Identifying, as indicated above, the basilica Liberii or Sicinini as the place where Ursinus was ordained would also help to determine the date of that ordination. If we assume that the

\footnotetext{
${ }^{119}$ See, e.g., LIPPOLD, Ursinus und Damasus, p.118. See also the chronological tables (of REUTTER, Damasus, Bischof von Rom, p.55; CoşKUn, Der Praefect Maximinus, p.43-44; and LIZZI TeSTA, Senatori, popolo, papi, p.169), which all locate Ursinus's ordination before Damasus's, albeit with the necessary question marks for the exact dates in question.

${ }^{120}$ DunN, Imperial Intervention, p.2, n.6, referring to C. H. TURNER, "The Papal Chronology of the Third Century," Journal of Theological Studies 17 (1915-1916), 338-353, p.341.

${ }^{121}$ For examples, see LiPPOLD, Ursinus und Damasus, p.119, n.73.

122 Coll. Av. 1,6: "Post dies septem cum omnibus periuris et arenariis, quos ingenti corrupit pretio, Lateranensem basilicam tenuit et ibi ordinatus episcopus".

${ }^{123}$ See LIZZI TESTA, Senatori, popolo, papi, p.144.

${ }^{124}$ D. TROUT (Damasus of Rome, p.6) entertains both possibilities, but prefers the earlier date. Most scholars now prefer 1 October, some 8 October.

125 The Liber Pontificalis reports a six-day vacancy after Liberius's death on 24 September 366 ("Et cessavit episcopatus dies VI", LP 37), leading to 1 October as the beginning of his successor's tenure. For the duration of Damasus's office, 18 years 3 months and 11 days is given ("sedit ann. XVIII. m. III d. XI", LP 39). Calculating back from Damasus's death on 11 December 384, one arrives at 1 September 366, which is before Liberius's death. Assuming an error of one month results exactly in 1 October 366.

126 See Coll. Av. 1,5: "Sibi Ursinum diaconum pontificem in loco Liberii ordinari deposcunt", and Coll. Av. 1,6: "Ursinus uir uenerabilis, qui prius fuerat pontifex ordinatus".

127 So ReutTer, Damasus, Bischof von Rom, p.43-44: "Die Weihe des Ursinus wird lediglich mit der kurzen Bemerkung Ursinum Paulus Tiburtinus episcopus benedicit konstatiert, wobei offenbar der terminus technicus für die Weihe ordinare, der bei Damasus verwendet wird, fehlt". Reuter (Damasus, Bischof von Rom, p.39) notices this also in Jerome's account of the facts: "Danach wurde zunächst Damasus ordiniert und kurze Zeit später Ursinus als Bischof festgesetzt, d.h. wohl nur gewählt".
} 
seven Ursinian priests who were brought to the basilica Liberii (Coll. Av. 1,6) assisted at this ceremony, it must have happened in October, and it must have happened before 26 October, since during the bloody confrontation on that day the building was severely damaged, most probably making it unfit for an ordination afterwards. So in our view, supported by the ancient historians and with some indications in the Gesta, Ursinus was not ordained in the basilica Iulii, but in the basilica Liberii, before 26 October. If these conclusions are correct, the ancient historians would have a case for locating Damasus's ordination before that of Ursinus.

In the end, however, the whole question of chronology needs to be put into perspective. What is really important is not the exact chronology of the events, nor even who was ordained first, but rather that regular procedure for a Roman episcopal ordination was followed; such was the case for Damasus.

\subsubsection{Consecrating bishop}

The Gesta mention that Ursinus was blessed (benedicit) by Bishop Paul of Tivoli ${ }^{128}$, but they do not give the name of the bishop who formally ordained the would-be pope ${ }^{129}$. The other sources either discredit the ordaining bishop or bishops as "inexperienced" (Rufinus), "of little distinction" (Socrates), "of little note" (Sozomen) ${ }^{130}$, or they do not mention the ordaining bishops at all (Jerome); nowhere, apart from the Gesta's mention of Paul of Tivoli, is a name given. Similarly, no source names the bishop or bishops who ordained Damasus. The assumption that Damasus was ordained by the bishop of Ostia, while possible, remains unproven ${ }^{131}$. It seems that ordination by the bishop of Ostia was traditional but not a requirement ${ }^{132}$. According to the fourth canon of Nicaea, the ordaining bishops should all be bishops from the surrounding area; the minimum number of such bishops was three, and in that case written consent of the other bishops in the area was to be obtained afterwards. The three traditional for the ordination of a Roman bishop were the ones from

${ }^{128}$ Coll. Av. 1,5: "Ursinum Paulus Tiburtinus episcopus benedicit".

129 As LIZZI TESTA observes in Senatori, popolo, p.148.

${ }^{130}$ Rufinus, Hist. Eccl., 11, 10 (English translation from Ph. AMIDON, Rufinus of Aquileia. History of the church (The Fathers of the Church. A New Translation, 133), Washington, D.C, The Catholic University of America Press, 2016, p.451);

SOCRATES, Hist. Ekkl., IV, 29, 3 (English translation from Ph. SCHAFF \& H. WACE, Socrates, Sozomenus: Church Histories, p.113);

SOzOMENOS, Hist. Ekel. VI, 23, 1 (English translation from SCHAFF \& WACE, Socrates, Sozomenus: Church Histories, p.359).

131 TROUT, Damasus of Rome, p.6; and PIETRI, Roma christiana, p.411-2 are both convinced that Damasus was ordained by Florentius, the bishop of Ostia. According to LIZZI TESTA, Senatori, popolo, papi, p.148, n.184, it is only an hypothesis that Damasus would have been consecrated by the bishop of Ostia. A similar statement is made by LIPPOLD, Ursinus und Damasus, p.119.

132 The opinion that ordination by the bishop of Ostia was a requirement, comes from an entry in the Liber Pontificalis (LP 34), which states that Pope Marcus initiated this tradition, and from the proof supposedly furnished by Augustine in his Brev. coll. cum Don. 3, 16, 29 where he refers to the ordination of the bishop of Rome: "sicut nec Romanae ecclesiae episcopum ordinat aliquis metropolitanus, sed de proximo Ostiensis episcopus". LIPPOLD, Ursinus und Damasus, p.116-117 adds that the note in the Liber Pontificalis is too uncertain, and that the text of Augustine's is only referring to the requirement that the ordaining bishop should come from the neighborhood. 
Ostia, Velletri, and Porto ${ }^{133}$. Since, as we have observed, Damasus tried to perform every step in the succession according to the rules, it is very probable that he was ordained by these bishops.

\subsection{Acclamation or public approval}

After Damasus's death in 384, Ursinus attempted to succeed him, this time in competition with Siricius. Once again, Ursinus failed to obtain the city's bishopric. In an imperial letter to the city prefect Pinianus, congratulating him on the succession of Rome, the emperor explains the failure of Ursinus as the result of popular acclamations against him and in favor of Siricius ${ }^{134}$.

For the election and consecration of a bishop at Rome, "In theory," as Pietri explains, "a consensus of the people, the clerics, and the neighboring bishops is needed to secure the appointment of a successor to Peter"135. The need for a consensus evolved from the practice of the second and third centuries, when the local community determined who became the new bishop ${ }^{136}$. Public approval or acclamation was thus a prerogative of the people in the choice for a bishop ${ }^{137}$.

It is significant that the Gesta contain no mention of an acclamatio for Ursinus; silence was probably maintained on this point because the absence of an acclamatio was unfavorable to Ursinus ${ }^{138}$. In other words, Ursinus failed to obtain a popular acclamation. The supporters of Damasus prevented precisely that with their assault on the basilica Iulii, where Ursinus had been elected ${ }^{139}$. Damasus, on the other hand, did obtain a public acclamation at the basilica Lateranensis, where he was ordained according to regular procedure ${ }^{140}$. The regularity of Damasus's election, namely, by acclamation, is attested in a letter of 384 sent to the court by Ambrose, who uses the words 'indicio Dei' to indicate that this unanimous acclamation by the people was seen as the expression of God's will. That Ursinus failed to obtain public

${ }^{133}$ De SPIRITO, Ursino e Damaso, p.269, n.24-25. For Rome this traditon was only established later, according to LIZZI TESTA, Senatori, popolo, p.148.

${ }^{134}$ Coll. Av. 4: "Proinde quoniam religiosum Siricium antistitem sanctitatis sic praeesse sacerdotio uoluerunt, ut Ursinum improbum acclamationibus uiolarent".

135 PIETRI, Roma cbristiana, p.680.

136 See LIZZI TESTA, Senatori, popolo, papi, p.148-149.

${ }^{137}$ RAIMONDI, Elezione iudicio Dei, p.203. The people could approve or disapprove a new bishop because of his moral qualities. For these, in the fourth century reference was made to $1 \mathrm{Tim}$. 3. For a more thorough treatment, M. Raimondi (Elezione iudicio Dei, p.203, n.152) refers to C. RAPP, Holy Bishops in Late Antiquity. The nature of Christian Leadership in an Age of Transition (The transformation of the classical heritage, 37), Berkeley, University of California press, 2005, p.32-40, where Rapp discusses the use of this scriptural text in late antiquity as a basis for pragmatic Christian leadership.

138 As implied by RAIMONDI, Elezione iudicio Dei, p.203-204.

139 LizZI TESTA, Senatori, popolo, papi, p.150: "Non acclamato dal popolo dopo l'ordinazione a causa dell'assalto dato alla chiesa dai seguaci di Damaso".

140 LIZZI TESTA, Senatori, popolo, papi, p.158: "acclamato dalla maggioranza del clero e del popolo, dopo essere stato ordinato nella cattedrale del Laterano". 
approval is noted by Ambrose in another letter to the court, dated in the year 381. Here Ambrose uses the words 'turpe convicium' to describe Ursinus as an unworthy candidate. ${ }^{141}$ Ambrose could not just be repeating pro-Damasus propaganda. The official character of the correspondence, the second letter being a report of the council of Aquileia of 381, is further support for its trustworthiness. In this way the authority of the bishop of Milan, together with the authority of an imperial letter, serve to confirm the legitimacy of Damasus's election and the illegitimacy of the election of Ursinus.

Without popular approval, the ordination of Ursinus was incomplete. Failure to obtain popular approval, and even receiving popular disapproval, made Ursinus an invalid candidate in the eyes of the authorities and the emperor, regardless of the relative chronology of the two elections.

\section{ASSESSMENT OF THE LEGITIMACY OF DAMASUS'S INSTALLATION}

If we adopt the Gesta as the main and privileged source of information for the conflict, then a pro-Ursinus, anti-Damasus conclusion is easily reached: "The Gesta inter Liberum et Felicem intend to illustrate both the way in which Damasus reached the episcopacy as well as the form, at the boundaries of regularity, in which his election took place. Compared to Ursinus, who was elected and ordained at the same time in the basilica Iulii iuxta forum Traiani, Damasus received in Lucinis only investiture and then had to wait for some time before he could proceed to the Lateran in order to receive consecration"142. To the eyes of some in the aristocracy, the installation of Ursinus looked to be more than valid, and it happened before the installation of Damasus. The opposing aristocratic faction, which supported Damasus, had to react by any means available to them, even by violence, in order to get their candidate on the See of Saint Peter ${ }^{143}$.

\footnotetext{
${ }^{141}$ In a letter to the court Ambrose referred to Damasus's election with the words "Romanae ecclesiae sacerdos iudicio dei electus" (Ep. X 72,10: Zelzer, CSEL 82.3, 16). The expression indicio Dei indicates that Damasus's election strictly followed the rules of ecclesiastical tradition, where unanimity of popular vote was seen to reflect the will of God. In another letter to the court (actually a letter of the council of Aquileia to the emperors, dated in 381, see FERRUA, Epigrammata Damasiana, p.74), the court is requested not to agree to requests for clemency on Ursinus' behalf. That letter recorded that Ursinus did not obtain public approval: 'quem cum 'habere' oportuerit 'testimonium etiam ab his qui foris sunt' quali testimonia cives proprii prosecuti sint clementia vestra meminisse dignetur. Pudet enim dicere, inverecimdum est recensere, quam turpi famam eius convicio sauciaverint" (Ep. ext. coll. 5, 5: Zelzer, CSEL 82.3, 184-85). In this fragment Ambrose not only clearly indicates that Ursinus was disapproved of by the citizens of Rome, he also mentions a possible typical outcome of such public acclamationes: Ursinus's reputation was compromised turpi convicio. RAIMONDI, Elerione iudicio Dei, p.197 and p.203.

${ }_{142}$ De SPIRITO, Ursino e Damaso, p.266-267.

${ }^{143}$ See Poglio, Gruppi di potere, p.146-147.
} 
If, however, we take some distance from the Gesta and look to the details of the installation process itself, it is Damasus who meticulously performed the necessary steps ${ }^{144}$; the process for Ursinus was less meticulous in adhering to these steps. Fundamentally, the election of Ursinus failed because he was not publically acclaimed, and he was not publically acclaimed because he only had the support of a minority of the people. "Ursinus may well have been elected and ordained first, but his consecration was imperfect"145. The refusal of the Ursinians to recognize this fact makes them partly responsible for the riots at the basilica Sicinini.

\section{CONCLUSION}

Relying on the Gesta as main source of information - it is indeed the most detailed source, but also extremely partisan - easily leads to the conclusion that Ursinus was the legitimate successor to Liberius. With the help of the admittedly scarce information available in other sources that are nearly contemporaneous with the disputed succession, and using the information in the Gesta against itself, a different conclusion can and should be reached. Damasus had a claim to be the legitimate successor of Liberius. It was Damasus, not Ursinus, who meticulously performed all necessary steps in the succession process: election by most of the clergy, approval by the majority of the people, ordination in the Lateran basilica (Rome's main church), and subsequent recognition by his peers. For Ursinus, at least one formal step was missing: he did not obtain public approval, which rendered his episcopal bid defective.

Chronological priority of election, an argument sometimes used, is difficult to establish. If Damasus was only nominated in the titulus in Lucinis, and not yet elected, then Ursinus's election happened before Damasus's. The exact place of the election appears to be unimportant for a determination of validity, but the location of the election could be an indication of the kind of support that each candidate obtained. Damasus's candidacy received support in Lucinis, from the area of his paternal roots, and Damasus succeeded in having the larger part of the deacons, priests, and people (plebs) behind him. Support for Ursinus in the basilica Iulii proved minoritarian; including himself, only three of the seven deacons were behind him, and his priestly support was possibly limited to the seven priests mentioned as at Ursinus's side in Coll. $A v$. 1,6. So Ursinus had a minority of the clergy, and the party of people that supported him was smaller than that of Damasus.

Acclamation, whether in favor of a candidate (iudicio Dei) or against a candidate (turpe convicium), was a necessary step in the succession process. Two different letters from the correspondence of Bishop Ambrose of Milan with the emperor speak to this issue. From the first, we know that Damasus did obtain public approval; from the second letter, we

\footnotetext{
144 So LIZZI TESTA, Senatori, popolo, papi, p.144; REUTTER, Damasus, Bischof von Rom, p.44; with reference to PIETRI, Roma christiana, p.411.

${ }^{145}$ LIZZI TESTA, Senatori, popolo, papi, p.150.
} 
learn that Ursinus was disapproved by the people. The official character of the letters are an argument for the legitimacy of Damasus's election.

Concerning the ordination ceremony of either Damasus or Ursinus, only scant information is furnished by the oldest sources. We are told little, for example, about Damasus's ordination. Apart from the late antique historians, who in their concision imply only that Damasus was ordained first, without mentioning the place, the time, or the bishops present, the only additional information is found in the Gesta, which state that the event happened in the basilica Lateranensis after a seven-day delay. Taking account of this delay and of the biographical data in the Liber Pontificalis yields a date of October $1^{\text {st }}, 366$ for the ordination of Damasus, who remained in office until December $11^{\text {th }}, 384$. Sources are just as silent on the consecration of Ursinus. Even the partisan Gesta provide only a few hints, one concerning the identity of the ordaining bishop and another asserting that Ursinus was ordained first. Some other late antique sources hint at the chronological priority of Damasus's ordination, or specify the place of Ursinus's ordination: the basilica Sicinini or Sicininum. So Ursinus's ordination too is poorly documented. It probably happened not in the basilica Iulii, where Ursinus was elected, but in the basilica Sicinini (called basilica Liberii in the Gesta), the location to which Ursinus and his supporters fled after the first violent confrontation with the party of Damasus. If Ursinus's consecration did take place in the basilica Liberii, then that consecration must have been later than Damasus's, which contradicts the testimony of the Gesta. The ordinations of both Damasus and Ursinus seem to have taken place in one or another regular basilica. With the limited information available, the names or number of bishops who assisted at the ordination of either candidate cannot be established, except for one reference in the Gesta to Paul of Tibur, or the late antique historians' assertion that Ursinus was ordained by bishops of little distinction. Information about the bishops who consecrated Damasus is entirely absent from the sources presently known.

The parallel elections of Damasus and Ursinus were not the only parallel elections for the bishopric of Rome. This particular succession process, however, was accompanied by serious violence. The most severe confrontation, at the basilica Sicinini, with over a hundred victims, merited an entry in the official data of the local administration and was therefore reported by Ammianus. At the moment itself, the city prefect withdrew from the scene, and the authorities did not intervene. Ursinus was later exiled several times as an instigator of continuous unrest in the Roman Christian community; Damasus, however, was allowed to remain in office, a possible indication that he was not held responsible for the violence. These exiles indirectly demonstrate that the authorities regarded Damasus rather than Ursinus as Liberius's rightful successor. In any case, the unusual violence casts a dark shade on the succession process in general and on the candidates themselves, on Ursinus, who failed to become Rome's bishop, and on Damasus, whose tenure lasted for about eighteen years. 